\title{
Editorial: Pickering, simplification and the American Civil War or ... the road to Hell ...
}

You cannot have too many reports. In one week in July 2002 the Sandler Report, a rather misbegotten (and probably soon-to-be-forgotten) lump of a report recommending standardised products to cope with perceived market failures, but not explaining why the market failed, came out. This was followed by the rather more thoughtful (but equally traduced by the press) report by Alan Pickering, followed yet a few days later by the House of Commons Select Committee on the Department of Work and Pensions announcing a complete investigation into the whole subject of pensions and the elephant problem.

If all the reports were laid end to end, the paper at least could be used to subsidise some little old lady's pension. Why have we got so many reports, no doubt with many others in the pipeline?

There seem to be two main causes. One is the lack of a vision anywhere at the top as to what the pension system should be in the UK. The complexity is, of course, legion. The solution, though there seems to be a general consensus on what it should be, is less well articulated. And the second issue is that of the carpetbaggers.

There are, of course, problems with the system. Individuals can put their faith in a company or insured pension and not receive what they were expecting. That leads to cynicism and lack of faith in the system, which is bad for all of us. The system itself is such that it discourages the provision of pension both by individuals and their employers. That is bad for all of us as individuals - as well as for the state, which is also all of us. And there are external forces - increased longevity, stresses in the stock market which are outside the control of policymakers, but which nonetheless affect decision making in the workplace.

Whether there is a crisis, as the Daily Mail insists there is, or whether there are merely some interim problems, is not yet clear. But that there are some problems seems indisputable. If we think that people should make some provision for their old age (or even for their retirement) then it is clear that the system at present does not encourage them to do so. If we want to change the system, what should we do?

Reform is an uneasy process. And the Pickering Report highlights that many of the reforms introduced for very good reasons over the last 30 years have had some rather discomforting, and possibly adverse, consequences. There are several obvious examples. The Pensions Act 1995 s67 provides that no change can be made to pension scheme rules that affects members' rights. Good in theory, but even beneficial improvements seem ruled out, and rearranging benefits to meet changing conditions, even if the benefits in the aggregate are unchanged, is almost impossible. The law has had the effect of making change difficult and very expensive — and has led to 
dissatisfaction and cynicism among employers who have to be able to move the goalposts to stay in the game. There was little evidence that the previous position, ie prior to the introduction of s67, had led to the widespread loss of benefits for scheme members; indeed trust law operated well, but as a much more flexible form of member protection.

Similarly, the minimum funding requirement, intended as a sensible protection of a member's promises, has had the counter-effect of adding to the costs of scheme provision, with little perceived benefit - and many employers feeling that the guarantees they now need to make are excessive and can destroy the sponsoring business itself. Also, many of the 'bells and whistles' designed to improve member representation, such as member-nominated trusteeship, have resulted in rules of considerable complexity and little added value to the consumer. Meanwhile, the regulator has been perceived to have pursued a box-ticking agenda at the expense of proportionality in its application of the rules, while being reluctant to take risks in making decisions designed to ameliorate the lot of pension funds (for example, refusing to give a blanket relief from the application of the minimum funding requirement (MFR) while stock markets were tumbling, knowing that it was government policy to remove the MFR at the earliest opportunity).

All this excessive rule-making and bureaucratic intervention came at a time when pension schemes were under material pressure to cut costs and reduce their exposure when the much excoriated FRS17 accounting rule, which required volatile valuations to be imposed on company balance sheets, has led to a reduction in many companies of pensions exposure.
How did we get ourselves into this sorry state? There are several reasons. First, the behaviour of our draftsmen; highly educated, with twin brains, able to dismantle the Times crossword at a single bound, but not able to express simple thoughts in a simple way. Our drafting arrangements, despite many attempts at reform, remain firmly wedded to 18th century layouts, design and typography, and 19th century forms of expression. It is not just their fault, of course. The parliamentary process is almost designed to obfuscate. A modern-day Jonathan Swift would have great delight in mocking the minute changes, and the parliamentary games played by otherwise intelligent people in changing one clause or another of what seemed at the time a reasonable document to produce a camel of an Act. The system is awry, and as a consequence the costs of compliance are excessive and the penalties for breach draconian.

Coupled with this abysmal legislative structure, we have the carpetbaggers. Unlike the carpetbaggers of earlier generations, they come filled with good cheer and a wish to put the world to rights; and God knows it looks as though it should be put to rights. But carpetbaggers in the pensions world usually have just one small idea. One problem may be that carpetbaggers are multi-skilled. The list is endless. Barbara Castle thought that SERPS would save the bacon for pensioners - but the cost was insupportable and the product unstable and in the end had to go. Meanwhile, there were years of complexity, the management of contracting-out and then she was also busy imposing speed limits and breathalyser tests. Richard Crossman invented a scheme, but it failed. Keith Joseph invented a scheme but it died because of a change of government. The 
state graduated scheme ( $\mathrm{Mr}$ Boyd-Carpenter) involved the deployment of huge resources for ultimately very little. Now we have stakeholder, State Second Pension (S2P), minimum income guarantee (MIG) and state pension credit, all four of them with probably limited life spans, and all invented by people with limited vision or at least limited involvement in pensions. They came, they saw, they legislated - but few of them stuck around to see whether the fruit of their endeavours were actually sweet or sour; and none of them paid any penalty for their grotesque errors.

Now we have the economist carpetbaggers: they have a little list also. They think that annuities have flaws (they do, but the alternatives are worse), that the public are too little educated about retirement income options (they are, but knowledge of plumbing or childcare would come higher up on the priority list), that rich people enjoy higher tax reliefs than poor people, and therefore enjoy better pensions than poor people, and therefore should not have tax relief on their pension contributions (true, but imposing the earnings cap has done as much damage to pension schemes for the less well paid than even FRS17).

It is, of course, true that anything can be improved. But it is not axiomatic that it should be. Sometimes the law of unintended consequences could, as has happened so often in the past, result in things becoming worse. Any reform needs to be holistic, rather than ad hoc; it is the ad hoc reforms that have caused the damage. Even Professor Goode, whose reforms held out so much hope in the field of consumer protection, has been seen with hindsight to have failed, perhaps again because although they were far-reaching, they were specific rather than holistic.
So what, if anything, should be done? Despite the dyspeptic press that the Pickering Report received, it contains the seed of radical and practical reform.

First, it hints that the government should get its own act in order. Which little old lady going to the post office to collect her pension can understand the interaction of the various state pension benefits, or on what basis her entitlements are calculated? We need a simple state retirement pension, flat rate, non-means tested, taxed, designed to take most people out of income support but not too generous that it disincentivises private provision - say £,120 per person per week, regardless of earnings record - and paid from, say, age 70 or 75 . Disability pensions could be paid earlier than that on proof of inability to work, as now.

That leaves the private sector to get its own act in order, which it would do if subject to basic tax principles and basic consumer protection. On the tax front, again, the structure could be simple and has already been outlined by the National Association of Pension Funds (NAPF) in a paper four years ago; no limits on inputs, no limits on outputs, no limits on funding - but tax on benefits, continued annuity compulsion to distinguish pensions from savings and, if there needs to be sumptuary constraints, tax limits on deductibility of salaries against company profits, rather than a complex earnings cap. The law could be expressed in a couple of pages, without the need for separate tax regimes, and the cost to the Treasury would be marginal, if anything at all. A draft of the proposed fiscal legislation was published by the NAPF in 1998 and seems to be pretty manageable.

Meanwhile, consumer protection legislation needs to follow the Pickering principles. These involve simplification, legislation by principle rather than detail 
(good news for lawyers, but better on balance) increased exposure to risk by members, coupled with increased notification of risk to members. And they also involve a reduction of risk for companies. It is this last which is now crucial for the survival of non-defined contribution (DC) schemes. This is not an argument for the continuation of defined benefit (DB) schemes, but for the survival of a wide variety of provision. And for lower-paid employees DB schemes offer much greater security of retirement income than DC schemes. They are the very people who suffer proportionately more in a market collapse than the better-off, and who can least afford to move to DC

arrangements. But the risks that employers have been forced to accept by changes in legislation over the years indexation, scheme design, accounting exposures - have meant that many employers, despite their best endeavours, have been artificially forced down one form of pension provision at the expense of another which they might prefer. And the financial and social cost of this has been material.

The Pickering suggestions are a breath of fresh air, but we need a gale of it.

The problem, therefore, is not that there is no need for reform, or even suggestions for reform; what we need is some drive for reform from the top, but a drive informed not by individual policy carpetbaggers, or rapidly revolving civil servants, but by senior elements in the government. There is no one person as yet charged with developing a holistic pensions policy, and that is what it needs, coupled with an agreement from the major political parties that whatever system emerges (hopefully along the lines described above) they will leave it well alone for anything up to 20 years, unless there really is an urgent need for change (and even then not just for short-term political gain). There is little in pensions that needs radical overhaul every five years, as we have had in the last 50 years. Moreover, the reform needs to be designed and implemented by the industry itself, which has no shortage of experienced scheme designers who have sufficient integrity.

The chances of radical and sensible reform are not high, but if not now, when? Pickering could be the catalyst for some sensible implementation in the next year or two - but if we do not have it, or it is designed by economists or Treasury officials, the consequences for many of the retiring population in the coming decades could be uncomfortable. Now we need a report, from the government this time, not from an independent observer as Pickering was, confirming that they are going to implement a state and private pensions policy avoiding so far as possible political agendas such as redistribution (honesty sometimes pays in politics), giving a timetable for implementation, and ratified by the opposition parties. One more report might do it.

Robin Ellison Editor

\section{Editor's note}

Readers may have noticed a new look and title to the Journal. The Editorial Board has taken on board the views of readers and has redesigned the publishing brief to reflect a more practical approach. The new style should result in more immediately practical applications of the papers and we hope you enjoy the fresh content and find the revamp has resulted in a more useful journal. Papers on policy and pensions scheme design will continue to be published, though less frequently than before. Meanwhile we welcome feedback from readers on style and content. 